\title{
TRANSIENT DRIFT SPECTROSCOPY FOR THE DETERMINATION OF THE SURFACE REACTION KINETICS OF $\mathrm{CO}_{2}$ METHANATION
}

\author{
MICHEL MARWOOD, RALF DOEPPER, MICHAEL PRAIRIE* and \\ ALBERT RENKEN $†$ \\ Institut de Génie Chimique, Ecole Polytechnique Fédérale, Ch-1015 Lausanne, Switzerland
}

(Received 16 May 1994; accepted for publication 12 Seprember 1994)

\begin{abstract}
Transient experiments were applied to the study of the adsorbed $\mathrm{CO}$ intermediate, $(\mathrm{CO})_{a}$, formed during the $\mathrm{CO}_{2}$ methanation reaction on a $2 \% \mathrm{Ru} / \mathrm{TiO}_{2}$ catalyst at $383 \mathrm{~K}$. Step-up experiments showed that the $(\mathrm{CO})_{a}$ formation steps are inhibited by $\mathrm{H}_{2} \mathrm{O}$ and enhanced by $\mathrm{H}_{2}$. Step-down experiments showed that the $(\mathrm{CO})_{a}$, hydrogenation is not influenced by the partial pressure of water. Based on the fact that water inhibits the overall $\mathrm{CO}_{2}$ methanation, it is deduced that the rate limiting process in the overall reaction is $(\mathrm{CO})_{a}$ formation.
\end{abstract}

\section{INTRODUCTION}

Heterogeneous catalytic reactions studied under steady-state conditions lead to overall lumped kinetic models that do not reflect a unique mechanistic physicochemical reality (Carberry, 1976; Baems et al., 1992). The transient behavior of the reaction is more sensitive to the elementary step rate constants (Renken, 1990). Therefore, dynamic experiments are used in order to distinguish between different models describing steady-state behavior.

The simultaneous measurement of the surfaceadsorbed species and the gas phase reactant-products considerably increases the amount of information available for the establishment of a kinetic model. Yet it is important to distinguish reactive-adsorbed species from spectator-surface species that do not participate in the reaction (Tamaru, 1991). Dynamic experiments can be used as a tool to understand the role of these observed species.

In this work, the kinetics of a surface reaction intermediate was studied by transient infrared experiments and compared to the steady-state kinetics obtained for the overall reaction. The aim was to gain more insight on the mechanism of formation and reaction of the observed reaction intermediate, as well as to determine which process is rate limiting in the overall reaction.

The reaction studied was the $\mathrm{CO}_{2}$ methanation reaction at $383 \mathrm{~K}$ on a $2 \% \mathrm{Ru} / \mathrm{TiO}_{2}$ catalyst. It is established in the literature that $(\mathrm{CO})_{a}$ is an important reaction intermediate in the $\mathrm{CO}_{2}$ methanation reaction (Henderson and Worley, 1985; Erdöhelyi et al., 1986). In this paper the kinetics of the $(\mathrm{CO})_{a}$ surface intermediates formed during the $\mathrm{CO}_{2}$ methanation

*Present address: Sandia National Laboratories, Albuquerque, NM 87185, U.S.A.

†To whom correspondence should be addressed. reaction on a $2 \% \mathrm{Ru} / \mathrm{TiO}_{2}$ catalyst are determined by diffuse reflectance infrared spectroscopy (DRIFTS) and are compared with the steady-state kinetics for the overall $\mathrm{CO}_{2}$ methanation reaction

\section{MATERIALS}

Transient experiments were performed in a single pass setup (Fig. 1) composed of a water evaporator and a controlled-environment DRIFTS cell. Feed was supplied through one of two banks of mass flow controllers that could be selected using a low-volume, four-way switching valve across which pressure and flow rate were equilibrated to avoid surges during switching. Reactor effluent composition was determined with a Balzers QMG 420 quadrupole mass spectrometer coupled with a two-stage continuous atmospheric sampling system. The DRIFTS cell (Harrick HVC-DR2 vacuum chamber with DRA1200 diffuse reflectance accessory) was located in a Nicolet 710 FTIR spectrometer equipped with a midrange $\mathrm{MCT}$ detector and a $\mathrm{KBr}$ beamsplitter. The instrument was operated at a scan speed of 1 scan s$^{-1}$, a resolution of $4 \mathrm{~cm}^{-1}$, and a number $(10-40)$ of interferograms were co-added depending on the time interval between each spectrum collection.

The water evaporator was made of a stainless steel U-tube filled with $1 \mathrm{~mm}$ glass beads and a small quantity of water. It was maintained at a temperature between $245 \mathrm{~K}$ and $283 \mathrm{~K}$ in order to vary the feed water pressure from a $P_{\mathrm{H}_{2} \mathrm{O}}$ value of 0.8 to 12.3 mbar.

The apparatus for the steady-state experiments consisted of a recycle reactor linked to the DRIFTS cell and is described elsewhere (Marwood et al., 1994). $\mathrm{CO}_{2}$ (99.995\%), $\mathrm{H}_{2}(99.9999 \%)$ and $\mathrm{He}$ (99.9999\%) gases were used after passing through Oxisorb traps that reduce oxygen impurity levels to less than $0.1 \mathrm{ppm}$. 


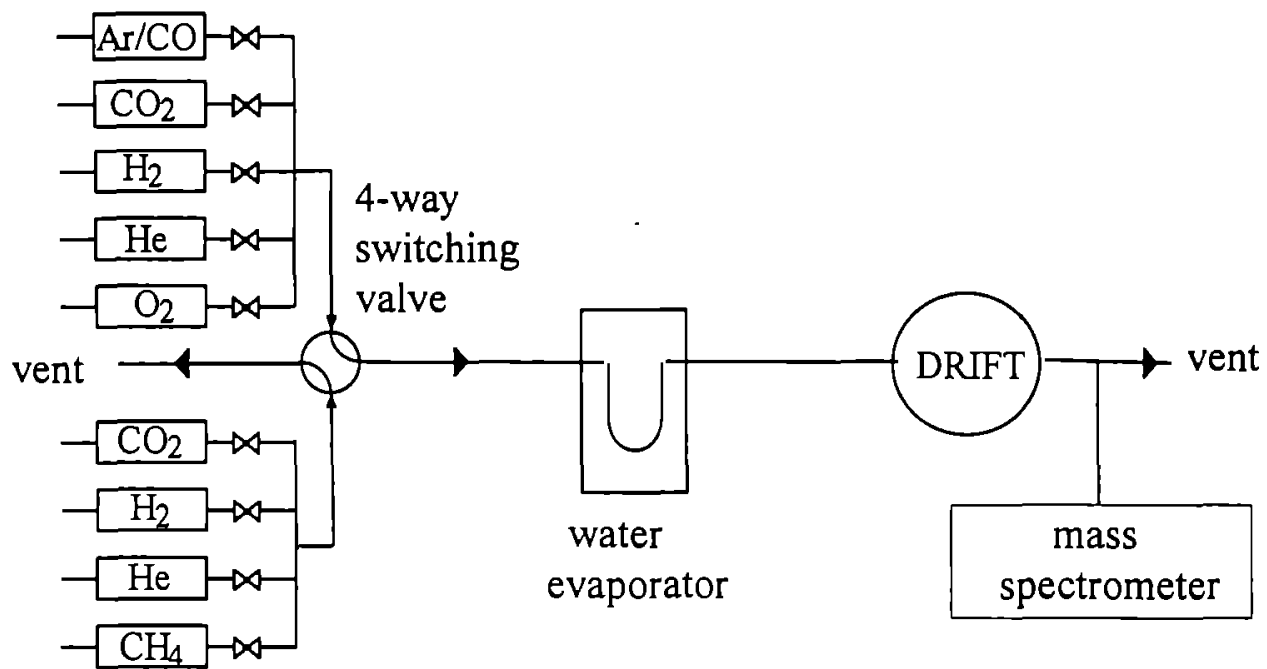

Fig. 1. Schematic layout of experimental apparatus.

\section{METHODS}

\section{Catalyst preparation}

The catalyst was ruthenium $(2.13 \mathrm{wt} \%)$ dispersed on $\mathrm{TiO}_{2}$ (Degussa P25) as described by Thampi et al. (1987). Standard pretreatment consisted of heating the catalyst to $498 \mathrm{~K}$ in flowing $40 \% \mathrm{O}_{2}$ for $1 \mathrm{~h}$ followed by a brief purge in $\mathrm{He}$ and a reduction in $20 \% \mathrm{H}_{2}$ at $498 \mathrm{~K}$. The catalyst was then cooled to $383 \mathrm{~K}$ in $20 \% \mathrm{H}_{2}$ and left to stabilize for $20 \mathrm{~min}$ before exposure to the reaction mixture. A $30 \mathrm{~min}$ exposure to $20 \% \mathrm{H}_{2}$ at $498 \mathrm{~K}$, as well as $20 \mathrm{~min}$ stabilization at $383 \mathrm{~K}$, was performed to clean the catalyst surface in between each transient experiment.

\section{IR data}

Infrared (IR) spectra were baseline corrected and represented in Kubelka-Munk (K-M) form, with a reference spectrum consisting of the clean catalyst in flowing $20 \% \mathrm{H}_{2}$ as described by Prairie et al. (1991b). The $(\mathrm{CO})_{a}$ data is represented by the integral of the IR band in the range $2070-1750 \mathrm{~cm}^{-1}$. The validity of such a representation was verified. Gaseous CO was adsorbed and the catalyst exposed to small pulses of $\mathrm{H}_{2}$. Consequently $(\mathrm{CO})_{a}$ reacted to form $\mathrm{CH}_{4}$ and the $(\mathrm{CO})_{a}$ IR band decreased. A linear relationship was observed between the $2070-1750 \mathrm{~cm}^{-1}$ band area and the $\mathrm{CH}_{4}$ formed for $\theta_{\text {CO }}$ between 0.1 and 1 .

\section{Transient experiments}

Step-up and step-down transient experiments were performed where the feed composition was changed from an initial to a final feed composition. The effects of the $\mathrm{H}_{2}$ and $\mathrm{H}_{2} \mathrm{O}$ partial pressures as well as the reaction temperature on the transient response were studied for a total flow rate of $50 \mathrm{Nml} / \mathrm{min}$. The experiments are summarized in Table 1.

Surface IR spectra were acquired at $20 \mathrm{~s}$ intervals during the first $5 \mathrm{~min}$ of the experiments and at $3 \mathrm{~min}$ intervals for the rest of the $40 \mathrm{~min}$ duration of the step-up experiments.

The step-down experiments were performed starting from the steady state with surface IR spectra acquired at $1 \mathrm{~min}$ intervals during the first $5 \mathrm{~min}$ period and at $3 \mathrm{~min}$ intervals for the rest of the experiment.

\section{RESULTS}

\section{Identification of adsorbed intermediates}

Figure $2 \mathrm{e}$ shows the spectrum obtained on the surface of $2 \% \quad \mathrm{Ru} / \mathrm{TiO}_{2}$ under steady-state $\mathrm{CO}_{2}$ methanation conditions. The interpretation of this IR spectrum is proposed by comparing it with the spectra of each of its individual components.

Figure 2d shows the spectrum of $2 \% \mathrm{Ru} / \mathrm{TiO}_{2}$ exposed at $383 \mathrm{~K}$ to flowing $40 \% \mathrm{CO}$ for $10 \mathrm{~min}$ followed by a $10 \mathrm{~min} \mathrm{He}$ purge to eliminate the gas phase $\mathrm{CO}$ absorbance bands, and $\mathrm{H}_{2}$ pulses in the $\mathrm{He}$

Table 1. Feed mixtures for transient experiments

\begin{tabular}{lccccc}
\hline No. & Feed initially & Switched to & mol\% $\mathrm{H}_{2}$ & $\boldsymbol{P}_{\mathrm{H}_{2} \mathrm{O}}$ (mbar) & $\mathrm{T}(\mathrm{K})$ \\
\hline$I^{\dagger}$ & $\mathrm{H}_{2}$ & $\mathrm{H}_{2}, 10 \% \mathrm{CO}_{2}$ & $5<x<50$ & 2.4 & 383 \\
2 & $\mathrm{H}_{2}$ & $\mathrm{H}_{2}, 10 \% \mathrm{CO}_{2}$ & 20 & $0.8-12.3$ & 383 \\
3 & $20 \% \mathrm{H}_{2}, 10 \% \mathrm{CO}_{2}$ & $\mathrm{H}_{2}$ & $2<x<50$ & 1.6 & 383 \\
4 & $20 \% \mathrm{H}_{2}, 10 \% \mathrm{CO}_{2}$ & $\mathrm{H}_{2}$ & 20 & $0.8-12.3$ & 383 \\
5 & $20 \% \mathrm{H}_{2}, 10 \% \mathrm{CO}_{2}$ & $\mathrm{H}_{2}$ & 20 & 6.1 & $363-413$ \\
\hline
\end{tabular}

$\dagger$ Total flow rate of $100 \mathrm{Nml} / \mathrm{min}$ instead of $50 \mathrm{Nml} / \mathrm{min}$. 


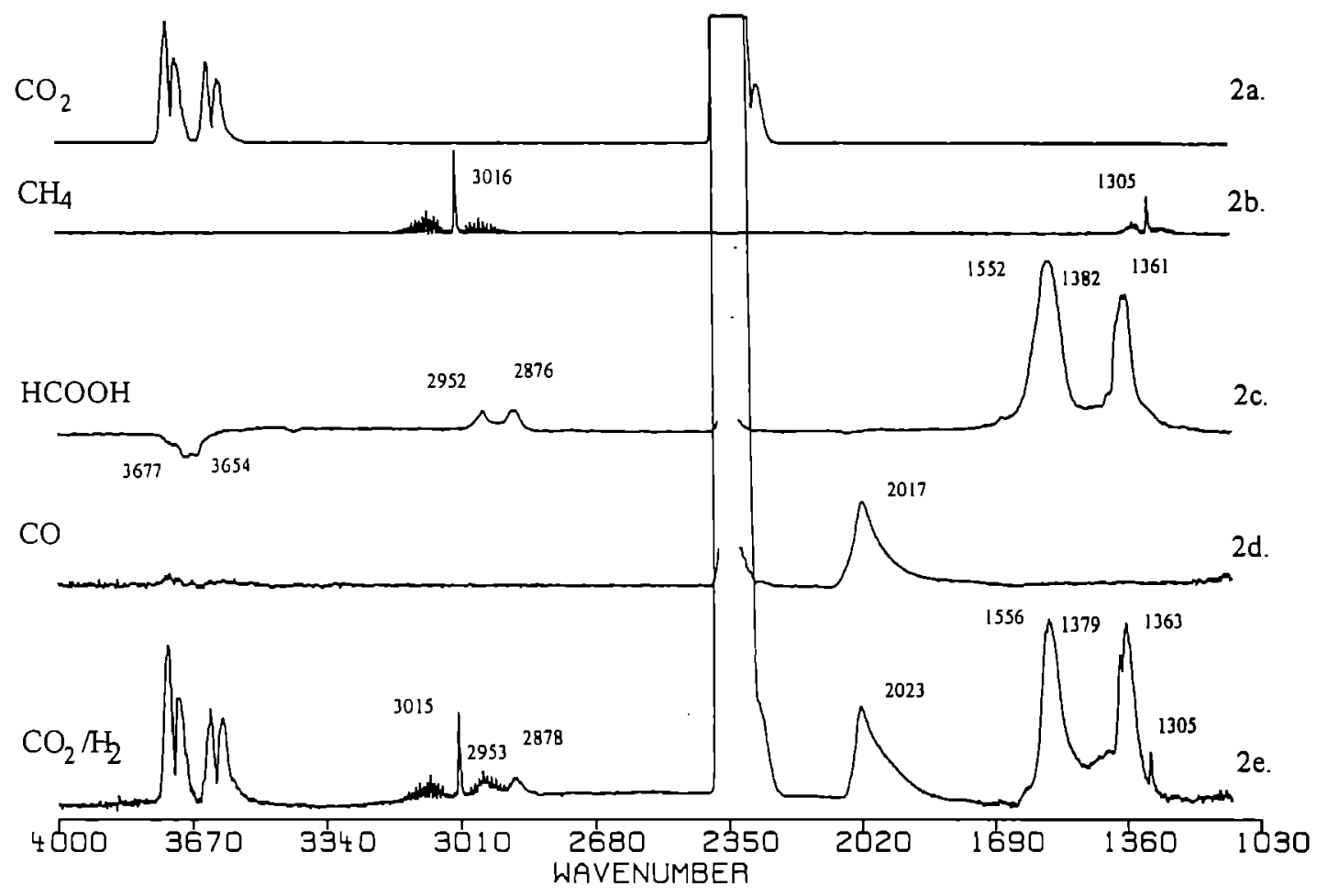

Fig. 2. DRIFTS spectra: a, gas phase $\mathrm{CO}_{2} ; b$, gas phase $\mathrm{CH}_{4} ; \mathrm{c}, \mathrm{HCOOH}$ adsorption on $2 \% \mathrm{Ru} / \mathrm{TiO}_{2}$; d, $\mathrm{CO}$ adsorption on $2 \% \mathrm{Ru} / \mathrm{TiO}_{2} ; \mathrm{e}, \mathrm{CO}_{2}$ methanation on $2 \% \mathrm{Ru} / \mathrm{TiO}_{2}$; spectra recorded at $383 \mathrm{~K}$.

carrier in order to diminish the $(\mathrm{CO})_{a}$ surface coverage. A large band was observed at $2045 \mathrm{~cm}^{-1}$ for total CO-coverage $\left(\theta_{\mathrm{CO}}=1\right)$ (Cant and Bell, 1982; Gupta et al., 1992). This coverage effect is well documented for $(\mathrm{CO})_{a}$ adsorbed on a metal surface (Sheppard and Nguyen, 1978). The $(\mathrm{CO})_{a}$ peak presented in Fig. 2e, with a maximum at $2017 \mathrm{~cm}^{-1}$, corresponds to $\theta_{\mathrm{CO}}=0.6$.

Figure $2 \mathrm{c}$ shows the spectrum of $\mathrm{TiO}_{2}$ at $383 \mathrm{~K}$ where $2 \mu \mathrm{l}$ of $\mathrm{HCOOH}$ were injected into the flowing He carrier. Two large bands at $1552 \mathrm{~cm}^{-1}$ and $136 \mathrm{I} \mathrm{cm}^{-1}$ arise from asymmetric and symmetric $\mathrm{O}-\mathrm{C}-\mathrm{O}$ stretching vibrations of adsorbed $\left(\mathrm{HCOO}^{-}\right)_{a}$ species (Busca et al., 1987). The $1382 \mathrm{~cm}^{-1}$ and $2876 \mathrm{~cm}^{-1}$ bands are attributed to the $\mathrm{CH}$ bending and stretching vibrations. The band at $2952 \mathrm{~cm}^{-1}$ results from a combination or overtones of $v_{(a) \mathrm{CO}_{2}^{-}}+\delta_{\mathrm{CH}}$. The two negative bands at $3677 \mathrm{~cm}^{-1}$ and $3654 \mathrm{~cm}^{-1}$ correspond to a decrease of free hydroxyls on the $\mathrm{TiO}_{2}$ surface. This decrease is due to $\left(\mathrm{HCOO}^{-}\right)_{a}$ formation by a condensation mechanism between $\mathrm{HCOOH}$ and these hydroxyl groups.

Figure $2 b$ shows the spectrum of gaseous $\mathrm{CH}_{4}$ characterized by two bands at 3016 and $1305 \mathrm{~cm}^{-1}$ associated with their rotational structure, and Fig. 2a shows the spectrum of gaseous $\mathrm{CO}_{2}$. The spectrum in Fig. 2e, obtained on $2 \% \mathrm{Ru} / \mathrm{TiO}_{2}$ under steady-state $\mathrm{CO}_{2}$ methanation conditions, can therefore be decomposed into two adsorbed species: $(\mathrm{CO})_{a}\left(2023 \mathrm{~cm}^{-1}\right)$ and $\left(\mathrm{HCOO}^{-}\right)_{a}\left(1360,1379,1555,2870,2948 \mathrm{~cm}^{-1}\right)$ as well as gaseous $\mathrm{CO}_{2}$ (reactant) and $\mathrm{CH}_{4}$ (reaction product).

\section{Steady-state kinetics}

At $383 \mathrm{~K}$, the $\mathrm{CO}_{2}$ steady-state methanation rate can be described by:

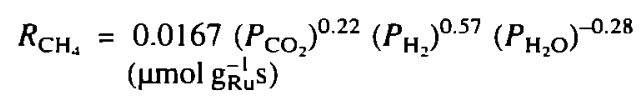

where the reaction rate is almost of order $1 / 2$ in hydrogen concentration and is inhibited by waterwater being a reaction product. A good correlation is obtained between measured and calculated data [eq. (1)]. The calculated values were found within a $10 \%$ interval relative to the measured data. An activation energy $E_{a}=80 \pm 4 \mathrm{~kJ} \mathrm{~mol}^{-1}$ was measured for the overall methanation reaction. This value is in good agreement with the value of $79 \mathrm{~kJ} \mathrm{~mol}^{-1}$ found by Prairie et al. (199la) for this reaction on a $3.8 \% \mathrm{Ru} /$ $\mathrm{TiO}_{2}$ catalyst.

\section{Step-up experiments}

In Fig. 3, gaseous $\mathrm{CO}_{2}, \mathrm{CH}_{4}$ and surface $(\mathrm{CO})_{a}$ are plotted together for a step-up experiment. $\mathrm{A} \mathrm{CO}_{2} \Rightarrow$ $(\mathrm{CO})_{a} \Rightarrow \mathrm{CH}_{4}$ sequence can be established. In additional experiments (Marwood, 1994) it was verified that $\mathrm{CH}_{4}$ is not adsorbed on the catalyst and $\mathrm{CO}$ adsorption from the gas phase is fast compared to (CO) $)_{a}$ formation from $\mathrm{CO}_{2}$. (CO coverage was found to follow the gas phase concentration in transient experiments without any time delay.) Besides $\mathrm{CH}_{4}$. water is formed and detected in the gas phase qualitatively following the methane curve. Due to the 


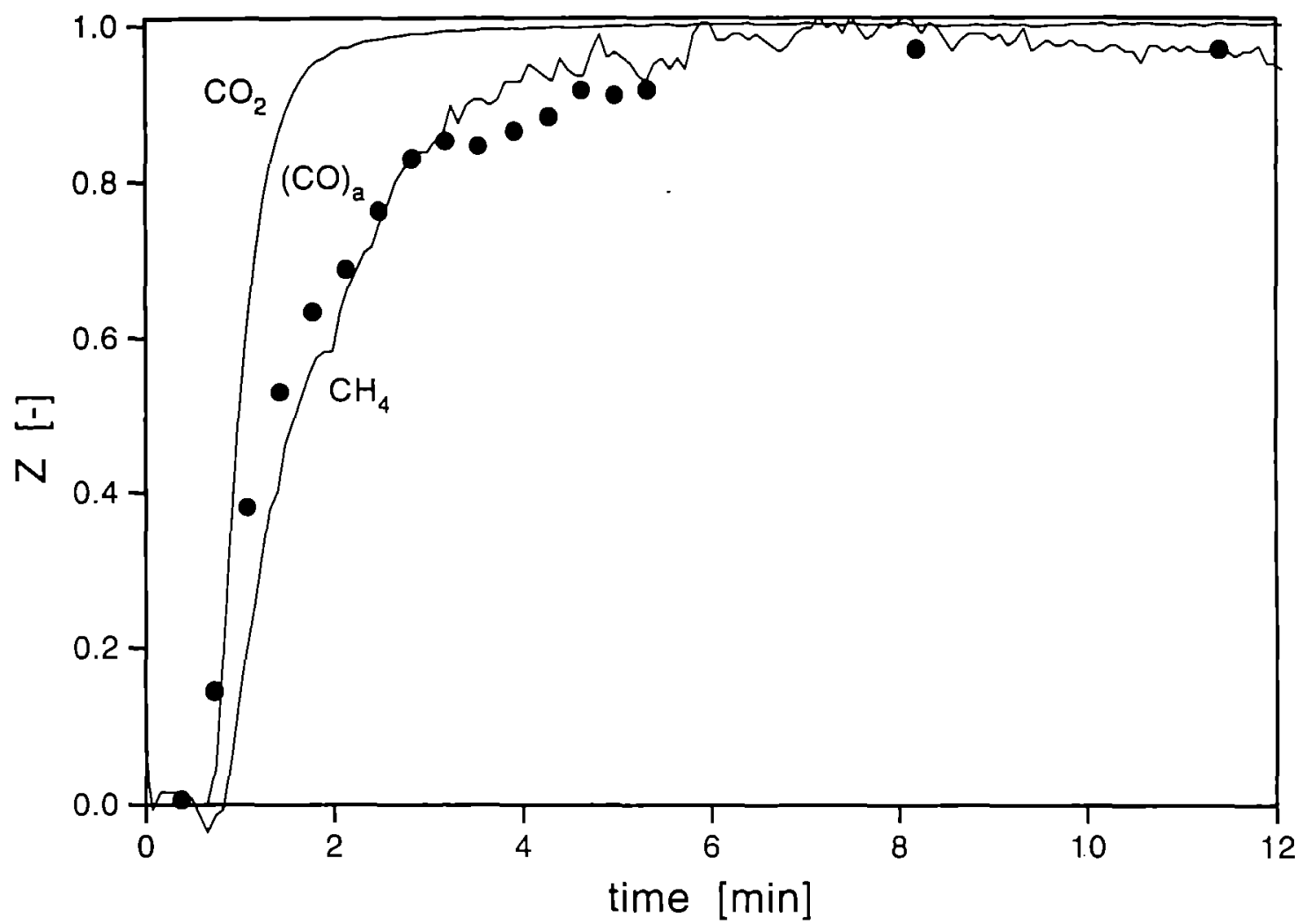

Fig. 3. Transient step-up experiment; feed switched from an initial composition of $20 \% \mathrm{H}_{2}$ in $\mathrm{He}$ to $10 \% \mathrm{CO}_{2}$ and $20 \% \mathrm{H}_{2}$ in $\mathrm{He}$ at $383 \mathrm{~K}$ and $P_{\mathrm{H}_{2} \mathrm{O}}=0.8 \mathrm{mbar}$.

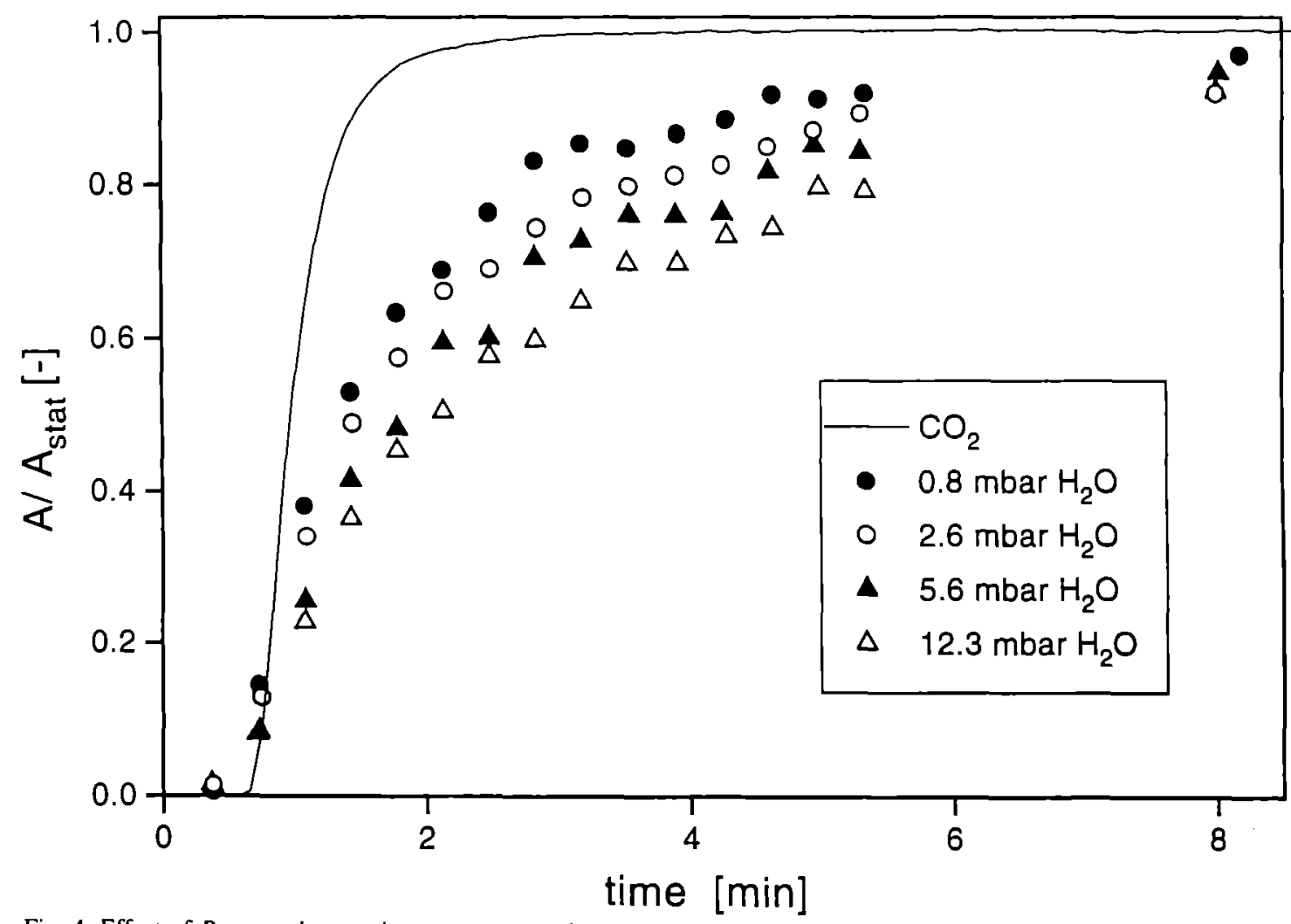

Fig. 4. Effect of $P_{\mathrm{H}_{2} \mathrm{O}}$ on the transient step-up experiment; normalized (CO) $)_{\lrcorner}$band integrals for a feed switched from an initial composition of $20 \% \mathrm{H}_{2}$ in $\mathrm{He}$ to $10 \% \mathrm{CO}_{2}$ and $20 \% \mathrm{H}_{2}$ in $\mathrm{He}$ at $383 \mathrm{~K} ; P_{\mathrm{H}_{2} \mathrm{O}}$ varying between 0.8 and 12.3 mbar. 
very low $\mathrm{CO}_{2}$ conversion in the DRIFTS cell, a quantitative determination of $\mathrm{H}_{2} \mathrm{O}$ by mass spectrometry is difficult. The transient response for water was therefore omitted in Fig. 3.

An inhibiting effect of $P_{\mathrm{H}_{2} \mathrm{O}}$ on the (CO) $)_{a}$ formation is shown in Fig. 4. The $(\mathrm{CO})_{a}$ data presented were normalized by the steady-state value obtained after 40 min of reaction. A definite effect of $\mathrm{H}_{2} \mathrm{O}$ on the $(\mathrm{CO})_{a}$ formation rate is observed. A decrease of this rate is observed with an increasing value of $P_{\mathrm{H}_{2} \mathrm{O}}$.

The (CO) $)_{a}$ formation is also influenced by the $\mathrm{H}_{2}$ concentration. An increasing value of $P_{\mathrm{H}_{2}}$ results in an increase of the $(\mathrm{CO})_{a}$ formation rate. The step-up experiments show that $\mathrm{H}_{2}$, as well as $\mathrm{H}_{2} \mathrm{O}$, plays an important role in the $\mathrm{CO}_{2}$ dissociation mechanism to form $(\mathrm{CO})_{a}$.

\section{Step-down experiments}

Typical IR data are presented in Fig. 5 for $(\mathrm{CO})_{a}$ hydrogenation at $383 \mathrm{~K}$ in $20 \mathrm{~mol}_{\%} \mathrm{H}_{2}$. These spectra were acquired at 3 min intervals. The uppermost spectrum was recorded during steady-state operation just before the switch. $(\mathrm{CO})_{a}$ band integrals were normalized against the spectrum recorded 2 min after the switch to account for the gas phase $\mathrm{CO}_{2}$ residence time in the system.

Figure 6 shows a semi-log plot of a normalized band area against time for varying $\mathrm{H}_{2}$ molar fractions. Good linearity is obtained up to $20 \% \mathrm{H}_{2}$. For $50 \% \mathrm{H}_{2}$ an order of 1.5 more adequately describes the data. The linearity of these data in a certain $\mathrm{H}_{2}$ concentration range suggests that $(\mathrm{CO})_{a}$ hydrogenation depends to first order on $\theta_{\mathrm{co}}$ within this range. Such a first-order dependence is in good agreement with

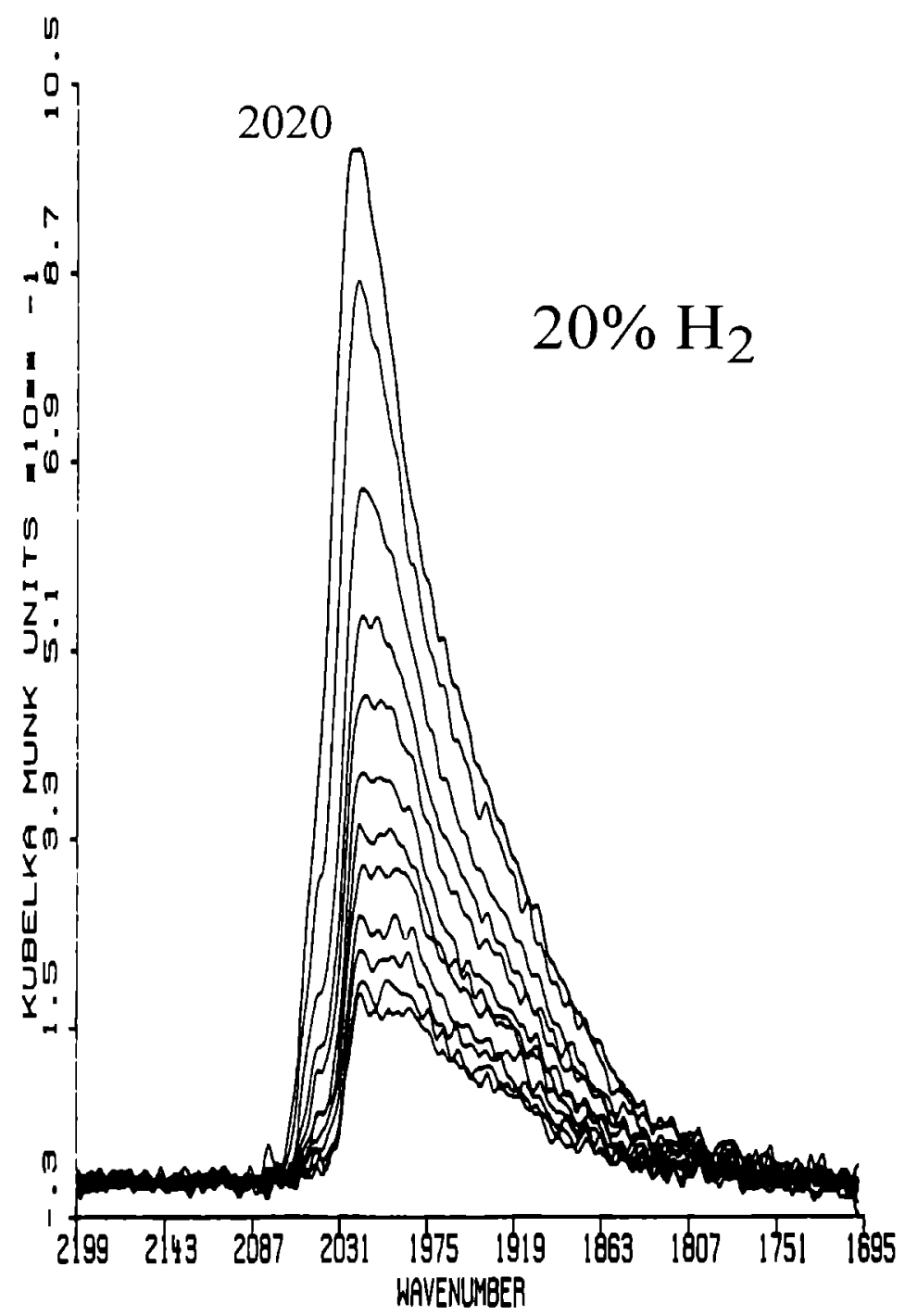

Fig. 5. DRIFTS spectra of $(\mathrm{CO})_{\text {" }}$ on $2 \% \mathrm{Ru} / \mathrm{TiO}_{2}$ during a transient step-down experiment. The spectra are recorded at $3 \mathrm{~min}$ intervals after a switch from an initial composition of $10 \% \mathrm{CO}_{2}$ and $20 \% \mathrm{H}_{2}$ in $\mathrm{He}$ to $20 \% \mathrm{H}_{2}$ in $\mathrm{He}$ at $383 \mathrm{~K}$; $\boldsymbol{P}_{\mathrm{H}, \mathrm{O}}=2.4 \mathrm{mbar}$. The uppermost spectrum was recorded at steady state in the $\mathrm{CO}_{2} / \mathrm{H}_{2}$ mixture immediately prior to the switch. 


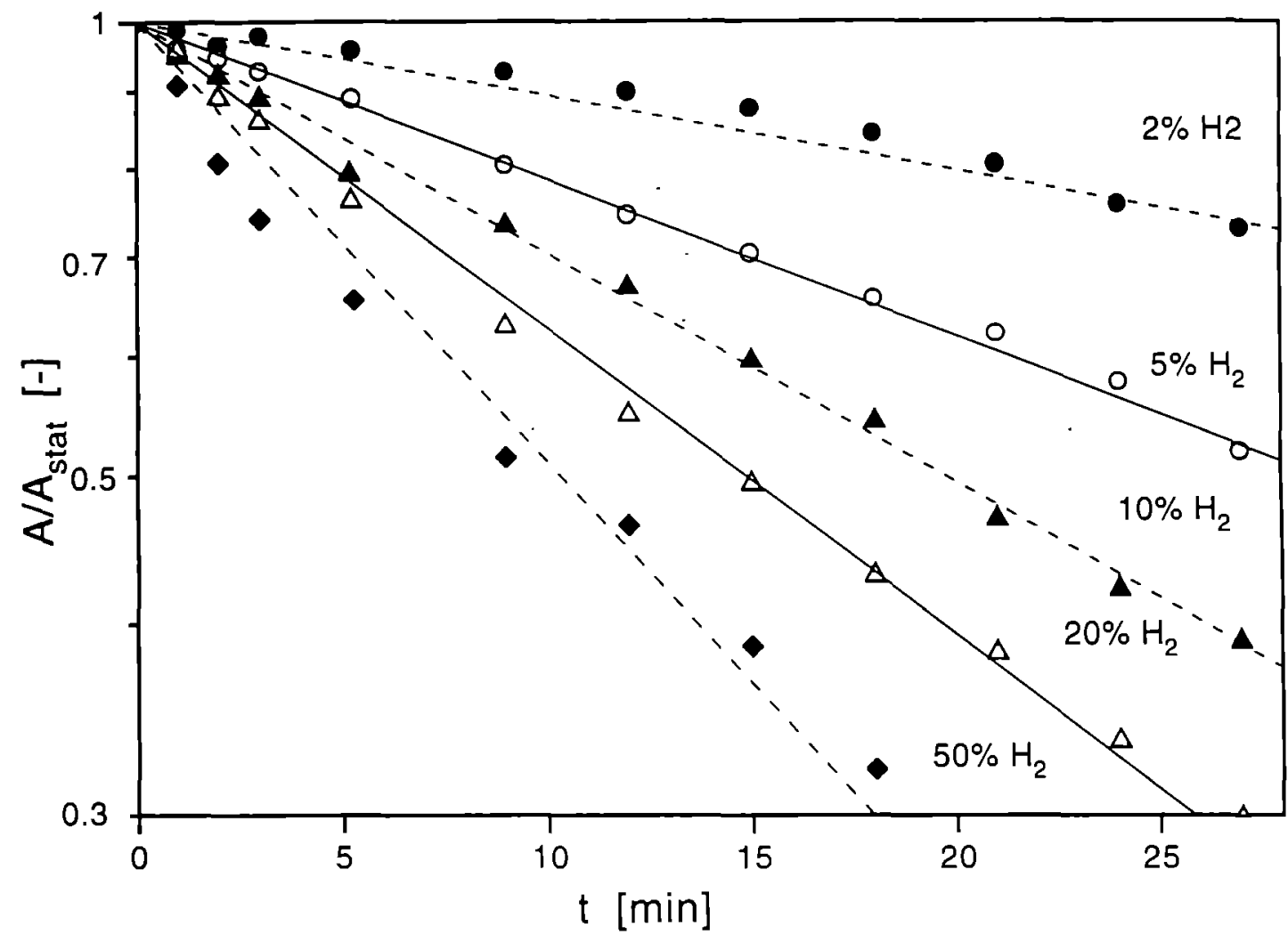

Fig. 6. Effect of $P_{\mathrm{H}_{3}}$ on the transient step-down experiment. Normalized (CO) $)_{a}$ band integrals for a feed switched from an initial composition of $x \% \mathrm{H}_{2}$ and $10 \% \mathrm{CO}_{2}$ in $\mathrm{He}$ to $x \% \mathrm{H}_{2}$ in $\mathrm{He}(2<x<50)$ at $383 \mathrm{~K} ; P_{\mathrm{H}_{2} \mathrm{O}}=1.6 \mathrm{mbar}$.

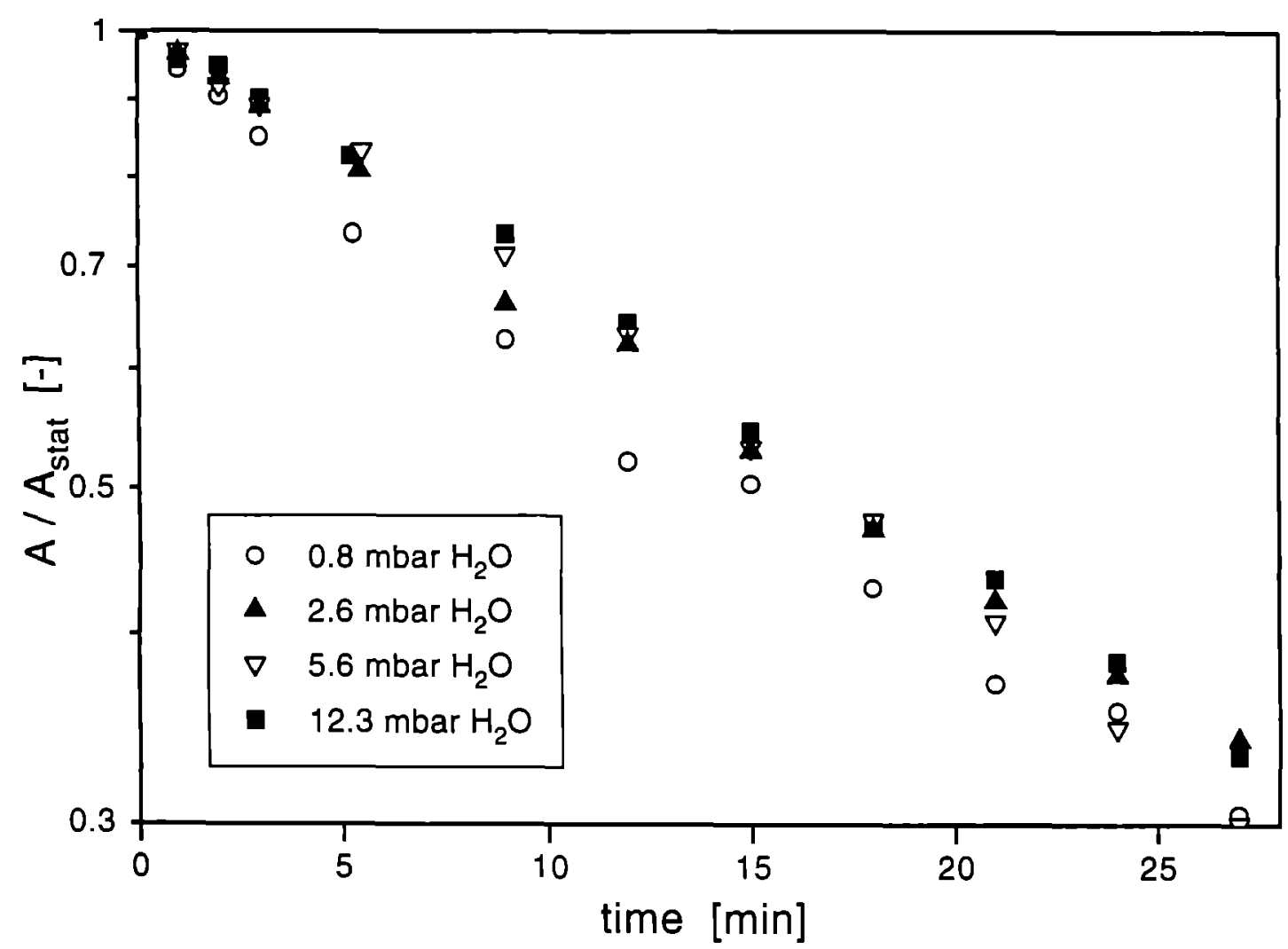

Fig. 7. Effect of $P_{\mathrm{H}_{2} \mathrm{O}}$ on the transient step-down experiment. Normalized (CO) ${ }_{a}$ band integrals for a feed switched from an initial composition of $20 \% \mathrm{H}_{2}$ and $10 \% \mathrm{CO}_{2}$ in $\mathrm{He}$ to $20 \% \mathrm{H}_{2}$ in $\mathrm{He}$ at $383 \mathrm{~K} ; P_{\mathrm{H}_{2} \mathrm{O}}$ varying between 0.8 and $12.3 \mathrm{mbar}$. 
results presented by Cant and Bell (1982) on a Ru/ $\mathrm{SiO}_{2}$ catalyst, or by Mori et al. (1982) and Tahri et al. (1993) on an $\mathrm{Ni} / \mathrm{SiO}_{2}$ catalyst:

$$
\begin{aligned}
\frac{\mathrm{d} \theta}{\mathrm{d} t} & =k \theta_{\mathrm{CO}} P_{\mathrm{H}_{2}}^{n}=k^{\prime} \theta_{\mathrm{CO}} . \\
k^{\prime} & =\mathrm{kP}_{\mathrm{H}_{2}}^{n}
\end{aligned}
$$

Slopes $k^{\prime}$ in a $\log$-log plot vs hydrogen concentration show that the hydrogenation of $(\mathrm{CO})_{a}$ has a half order dependence on hydrogen concentration.

The hydrogenation of $(\mathrm{CO})_{a}$ is independent of the $\mathrm{H}_{2} \mathrm{O}$ partial pressure as is shown in Fig. 7. This observation is important if it is combined with the fact that water inhibition was measured under steadystate conditions for the overall $\mathrm{CO}_{2}$ methanation reaction.

Figure 8 shows a semi-log plot of the normalized band area against time for six temperatures. The slopes in this figure represent the reaction rate constant $k^{\prime}$ which is an intrinsic function of temperature. Plotting k' vs temperature in the Arrhenius form yields an apparent activation energy of 62 $\pm 3 \mathrm{~kJ} \mathrm{~mol}^{-1}$.

In summary, the hydrogenation of metal-adsorbed $\mathrm{CO}$ on the $2 \% \mathrm{Ru} / \mathrm{TiO}_{2}$ catalyst obeys the following kinetic expression at atmospheric pressure and temperatures up to $413 \mathrm{~K}$.

$$
r=c s t \exp (-62,000 / R T) \theta_{\mathrm{CO}} P_{\mathrm{H}_{2}}^{0.5} \text {. }
$$

\section{DISCUSSION}

The $\mathrm{CH}_{4}$ production in the step-up experiment shown in Fig. 3 is delayed, indicative of $\mathrm{CH}_{4}$ production through a series of consecutive reaction steps. The comparatively faster initial rate of formation of $(\mathrm{CO})_{a}$ makes this surface species a very plausible surface intermediate. The observation that $\mathrm{H}_{2}$ catalyses while $\mathrm{H}_{2} \mathrm{O}$ inhibits (Fig. 4) the $(\mathrm{CO})_{a}$ formation rate has to be taken into account in the establishment of a mechanism leading to $(\mathrm{CO})_{a}$. Clearly these observations show that $(\mathrm{CO})_{a}$ is not formed by simple $\mathrm{CO}_{2}$ dissociation. The reverse water-gas shift reaction (RWGS) proposed by Prairie et al. (199la) on the basis that the steady-state (CO) concentration is negatively influenced by $\mathrm{H}_{2} \mathrm{O}$ is consistent with the observed $\mathrm{H}_{2}$ and $\mathrm{H}_{2} \mathrm{O}$ effect in the transient step-up experiments. The mechanism of the RWGS is thought to either go through a formate intermediate (Schild et al., 1991; Shido and Iwasawa, 1993) or through a "surface redox" process (Emst $e t$ al., 1992; Fujita et al., 1992). Spectroscopic surface experiments performed in this system where $\left(\mathrm{HCOO}^{-}\right)_{a}$ surface adsorbates are measured tend to favor the formate mechanism in the following form:

$$
\begin{aligned}
\mathrm{CO}_{2}+\mathrm{OH}^{-} & \rightleftarrows\left(\mathrm{HCO}_{3}^{-}\right)_{a} \\
\left(\mathrm{HCO}_{3}^{-}\right)_{a}+2(\mathrm{H})_{a} & \rightleftarrows\left(\mathrm{HCOO}^{-}\right)_{a}+\mathrm{H}_{2} \mathrm{O} \\
\left(\mathrm{HCOO}^{-}\right)_{a} & \rightleftarrows(\mathrm{CO})_{a}+\mathrm{OH}^{-} \\
\hline \mathrm{CO}_{2} \mathrm{H}_{2} & \rightleftarrows(\mathrm{CO})_{a}+\mathrm{H}_{2} \mathrm{O} .
\end{aligned}
$$

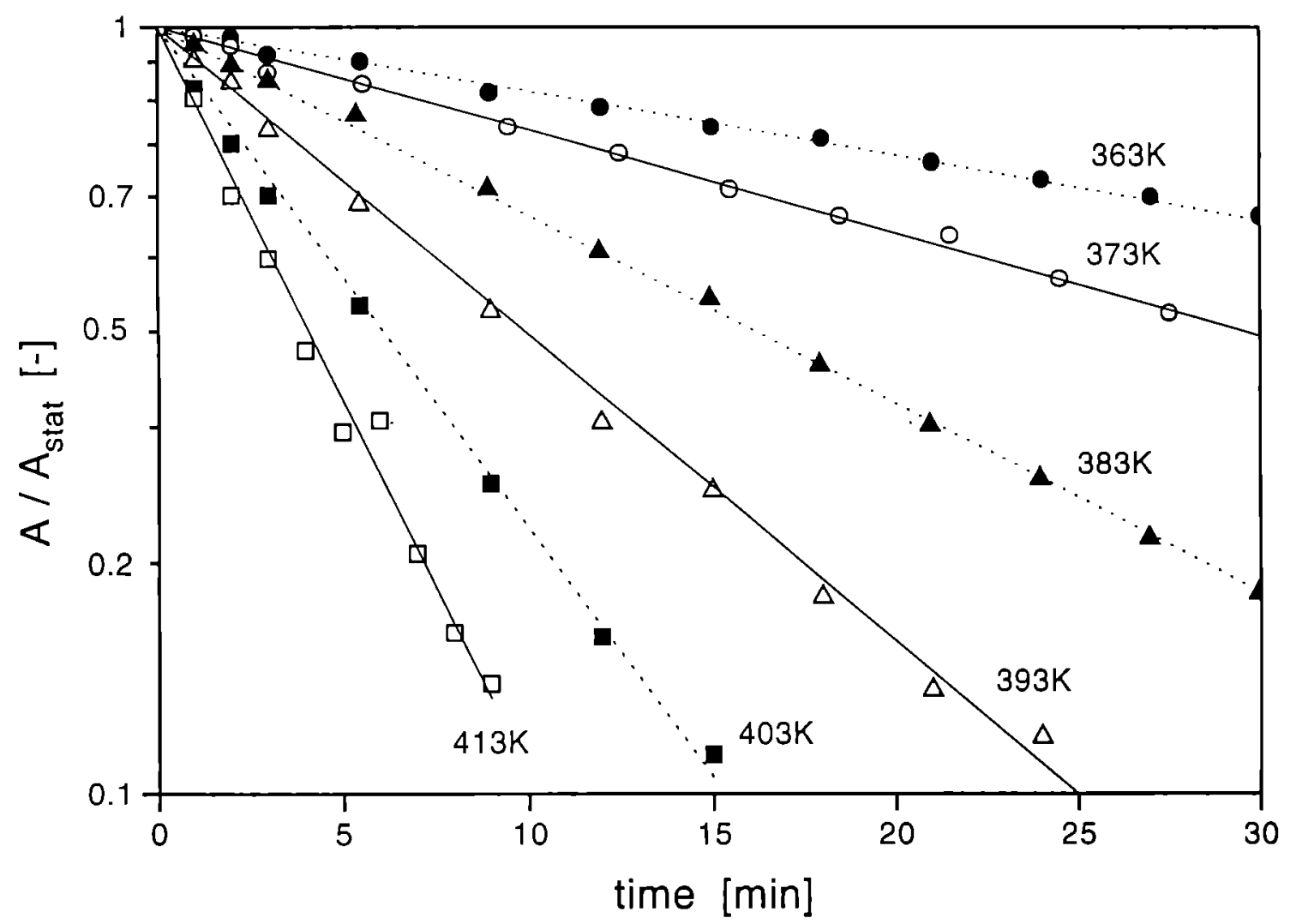

Fig. 8. Effect of the reaction temperature on the transient step-down experiment. Normalized (CO), band integrals lor a liced switched from an initial composition of $20 \% \mathrm{H}_{2}$ and $10 \% \mathrm{CO}_{2}$ in $\mathrm{He}$ to $20 \% \mathrm{H}_{2}$ in $\mathrm{He} ; P_{\mathrm{H}_{2} \mathrm{O}}=6.1$ mball will reaction temperature varying between 363 and $413 \mathrm{~K}$. 
This mechanism is based on the observations that:

(1) $\left(\mathrm{HCOO}^{-}\right)_{a}$ is not formed in the absence of $\mathrm{H}_{2}$ or $\mathrm{Ru}$ to dissociate the $\mathrm{H}_{2}$.

(2) $\left(\mathrm{HCO}_{3}^{-}\right)_{a}$ is observed on the catalyst surface or on a blank composed of the $\mathrm{TiO}_{2}$ support upon exposure to $\mathrm{CO}_{2}$. A $\mathrm{CO}_{2} \Rightarrow \mathrm{CO}_{2} / \mathrm{H}_{2}$ switch results in the decrease of the $\left(\mathrm{HCO}_{3}^{-}\right)_{a}$ while $\left(\mathrm{HCOO}^{-}\right)_{a}$ appears on the catalyst surface. No modification of $\left(\mathrm{HCO}_{3}^{-}\right)_{a}$ is observed on the blank $\mathrm{TiO}_{2}$ surface.

(3) Negative hydroxyl bands are measured on the IR spectrum of the catalyst surface after steady-state reaction.

(4) The positive effect of $\mathrm{H}_{2}$ concentration on the $(\mathrm{CO})_{a}$ formation as well as the inhibiting effect of $\mathrm{H}_{2} \mathrm{O}$ are compatible with this mechanism.

A similar mechanism was proposed by $\mathrm{Fu}$ et al. (1989) for the water-gas shift reaction on a K-Os/ $\mathrm{Al}_{2} \mathrm{O}_{3}$ catalyst.

The observation of a one-half order dependence on $\mathrm{H}_{2}$ concentration for the $(\mathrm{CO})_{a}$ hydrogenation process indicates that $(\mathrm{CO})_{a}$ methanation has a firstorder relationship with adsorbed $(\mathrm{H})_{a}$ concentration which is in equilibrium with gas phase $\mathrm{H}_{2}$ via a dissociative adsorption process. Neither $(\mathrm{CO})_{a}$ coverage nor methanation seem to perturb this equilibrium. Similar results for $(\mathrm{CO})_{a}$ methanation on $\mathrm{Ru} /$ $\mathrm{SiO}_{2}$ were also reported by Cant and Bell (1982). Water concentration has no effect on the hydrogenation of $(\mathrm{CO})_{a}$. Water inhibition was measured under steady-state conditions for the overall $\mathrm{CO}_{2}$ methanation reaction. Inhibition by water must act on the $(\mathrm{CO})_{a}$ formation steps if $(\mathrm{CO})_{a}$ is to be a reaction intermediate in the $\mathrm{CO}_{2}$ methanation reaction. Such an inhibiting effect of water on the $(\mathrm{CO})_{a}$ formation was indeed observed during the step-up experiment. This indicates that the rate limiting process of the overall methanation reaction is the $(\mathrm{CO})_{a}$ formation.

The overall $\mathrm{CO}_{2}$ methanation reaction exhibits an activation energy of $80 \mathrm{~kJ} \mathrm{~mol}^{-1}$ for $2 \% \mathrm{Ru} / \mathrm{TiO}_{2}$. This value is in good agreement with the literature where values ranging between 67 and $88 \mathrm{~kJ} \mathrm{~mol}^{-1}$ are reported. For the process of $(\mathrm{CO})_{a}$ methanation, an activation energy of $62 \mathrm{~kJ} \mathrm{~mol}^{-1}$ is measured. Thus, no elementary step in the pathway between $(\mathrm{CO})_{a}$ and $\mathrm{CH}_{4}$ can be the limiting step in the overall $\mathrm{CO}_{2}$ methanation reaction. However, $(\mathrm{CO})_{a}$ accumulation is observed on the catalyst surface under steady state. The accumulation of a reaction intermediate placed after the rate limiting step in a consecutive reaction scheme is controlled by the ratio of the rate limiting step reaction constant by the reaction intermediate consumption rate. The observed $(\mathrm{CO})_{a}$ accumulation thus indicates that the $(\mathrm{CO})_{a}$, hydrogenation process is of the same order of magnitude as the $(\mathrm{CO})_{a}$ formation process. A similar conclusion was reached with periodic variations of $\mathrm{CO}_{2}$ in the $\mathrm{H}_{2}$ feed (Marwood et al., 1994).

\section{CONCLUSIONS}

The transient kinetic study of the $(\mathrm{CO})_{a}$ surface intermediate shows that the $(\mathrm{CO})_{a}$ formation steps are inhibited by $\mathrm{H}_{2} \mathrm{O}$ and enhanced by $\mathrm{H}_{2}$. A RWGS mechanism, based on spectroscopic observations, is postulated and can explain the observed $\mathrm{H}_{2} \mathrm{O}$ and $\mathrm{H}_{2}$ trends. Although the transient behavior of catalysts differs from steady state (Renken, 1993), the following conclusion can be drawn.

The fact that $(\mathrm{CO})_{a}$ hydrogenation in the transients is independent of $\mathrm{H}_{2} \mathrm{O}$ concentration, as opposed to the observation of $\mathrm{H}_{2} \mathrm{O}$ inhibition under steady-state conditions, may indicate that the rate limiting process in the overall $\mathrm{CO}_{2}$ methanation reaction is the formation of $(\mathrm{CO})_{a}$. A similar conclusion is reached by comparing the apparent activation energies for $(\mathrm{CO})_{a}$ hydrogenation and the overall steady-state reaction. $(\mathrm{CO})_{a}$ accumulation on the catalyst surface reflects a $(\mathrm{CO})_{a}$ hydrogenation rate constant of a similar order of magnitude to the rate limiting process.

Acknowledgments - The authors are grateful to the Swiss National Science Foundation for financial support.

\section{NOTATION}

A

integrated $(\mathrm{CO})_{a}$ infrared band between 2070 and $1750 \mathrm{~cm}^{-1}$

$A_{\text {stat }}$ steady-state value of the integrated $(\mathrm{CO})_{a}$ infrared band under $\mathrm{CO}_{2}$ methanation

$E_{a} \quad$ apparent activation energy

$k^{\prime} \quad$ rate coefficient for the $(\mathrm{CO})_{a}$ hydrogenation step

$P_{\mathrm{H}_{2}} \quad$ hydrogen partial pressure

$P_{\mathrm{H}_{2} \mathrm{O}} \quad \mathrm{H}_{2} \mathrm{O}$ partial pressure

$r \quad(\mathrm{CO})_{a}$ hydrogenation rate

$R_{\mathrm{CH}_{\lrcorner}} \quad$ methane formation rate

$Z$ dimensionless variable, normalized by the steady-state value of the variable

Greek letter

$\theta_{\mathrm{CO}}$ fractional surface coverage by $\mathrm{CO}$

\section{REFERENCES}

Baerns, M., Hofmann, H. and Renken, A., 1992, Chemische Reakrionstechnik, 2nd edn, p. 55, Georg Thieme Verlag, Stutigart.

Busca, G., Lamotte, J., Lavalley, J-C. and Lorenzelli, V., 1987, FT-IR study of the adsorption and transformation of formaldehyde on oxide surfaces. J. Am. Chem. Soc. 109, 5197-5202.

Cant, N. W. and Bell, A. T., 1982, Studies of carbon monoxide hydrogenation over ruthenium using transient response techniques. J. Catal. 73, 257-271.

Carberry, J. J., 1976, Chemical and Caralytic Reaction Engineering, p. 388. McGraw-Hill, New York.

Erdöhelyi, A., Pásztor, M. and Solymosi, F. , 1986, Catalytic hydrogenation of $\mathrm{CO}_{2}$ over supported palladium. $J$. Catal. 98, 166-177.

Emst, K.-H., Campbell, C. T. and Moretti, G., 1992, Kinetics of the reverse water-gas shift reaction over $\mathrm{Cu}(\mathrm{l} 10)$. J. Caral. 134, 66-74.

Fu, Y., Kraus, L. and Knözinger, H., 1989, Formation and reactivities of formate species on a potassium-modified osmium/alumina catalyst: an infrared spectroscopic 
study. J. Mol. Catal 52, 113-127.

Fujita, S.-I., Usui, M. and Takezawa, N., 1992, Mechanism of the reverse water gas shift reaction over $\mathrm{Cu} / \mathrm{ZnO}$ catalyst. J. Coral. 134, 220-225.

Gupta, N. M., Kamble, V. S., Iyer, R. M., Thampi, K. R. and Grätzel, M., 1992, The transient species formed over Ru$\mathrm{RuO}_{\mathrm{x}} / \mathrm{TiO}_{2}$ catalyst in the $\mathrm{CO}$ and $\mathrm{CO}+\mathrm{H}_{2}$ interaction: FTIR spectroscopic study. J. Catal. 137. 473.

Henderson, M. A. and Worley, S. D., 1985, An infrared study of the hydrogenation of carbon dioxide on supported rhodium calalysts. J. Phys. Chem. 89 1417-1423.

Marwood, M., Van Vyve, F., Doepper, R. and Renken, A., 1994, Periodic operation applied to the kinetic study of $\mathrm{CO}_{2}$ methanation. Catalysis Today. in press.

Mori, T., Masuda, H., Imai, H., Miyamolo, A., Baba, S. and Murakami, Y., 1982, Kinetics, isotope effects, and mechanism for the hydrogenation of carbon monoxide on supported nickel catalysts. J. Phys. Chem. 86. 2753-2760.

Prairie, M. R., Highfield, J. G. and Renken, A., 199la, Diffuse-reflectance FTIR spectroscopy for kinetic and mechanistic studies of $\mathrm{CO}_{2}$ hydrogenation in a continuous recycle reactor. Chem. Engng Sci. 46. 113-121.

Prairie, M. R., Highfield, J. G., Renken, A., Thampi, K. R. and Grätzel, M., 199lb, A Fourrier transform infrared spectroscopic study of $\mathrm{CO}_{2}$ methanation on suppored ruthenium. J. Catal. 129, 130-144.

Renken, A., 1990, Application of unsteady state processes in modelling heterogeneous catalytic kinetics, in Unsteady
State Processes in Catalysis (Ediled by Yu. Sh. Matros), pp. 183-202. VSP, Utrecht.

Renken, A., 1993, Transient operation for the purpose of modeling heterogeneous catalytic reactions. Int. Chem. React. Engng 33, 6I-7I.

Schild, C., Wokaun, A. and Baiker, A., 1991, Surface species in $\mathrm{CO}_{2}$ methanation over amorphous palladium/ zirconia catalysts. J. Mol. Calal. 69, 347-357.

Sheppard, M. and Nguyen, T. T., 1978, The vibrational spectra of carbon monoxide chemisorbed on the surfaces of metal catalysts - a suggested scheme of interpretation. Advances in Infrared and Raman Spectroscopy, Vol. 5 (Edited by R. J. H. Clark and R. E. Hester), pp. 67-148. Heydn and Son.

Shido, T. and Iwasawa, Y., 1993, The effect of coadsorbates in reverse water-gas shift reaction on $\mathrm{ZnO}$, in relation to reactant-promoted reaction mechanism. J. Catal. 140, 575-584.

Tamaru, K., 1991, Dymamic Relaxation Methods in Heterogeneous Catalysis, Caralysis: Science and Technology, Vol. 9 (Ediled by J. R. Anderson and M. Boudar), p. 88. Springer Verlag.

Tahri, A., Amariglio, A., Zyad. M. and Amariglio, H., 1993, Processus réactionnels accompagnant la chimisorption du dioxyde de carbone sur un catalyseur au nickel en relation avec la réaction de méthanation. J. Chim. Phys. 90, $109-121$.

Thampi. K. R., Kiwi, J. and Grälzel, M., 1987, Methanation and pholo-methanation of carbon dioxide al room temperature and atmospheric pressure. Nature 327, 506. 